\title{
POLICIES AND STRATEGIES FOR THE PROMOTION AND ATTRACTION OF FDI IN SERVICES
}

\author{
Vesna Babić-HODOVIC \\ Eldin MEHIC \\ School of Economics and Business, Bosnia and Herzegovina
}

\begin{abstract}
In this paper we present results of the research conducted with the goal to test main determinants that influence FDI stock in services, in order to propose policies and strategies for promoting FDI in services for transition countries, more precisely in CEE countries. Some of the conceptual issues identified under FDI in services that we started with are: 1)What are the most important determinants of FDI in services in CEE?; and 2) Which policies and strategies for promotion and attraction of FDI in services could developing economies - CEE use?

The dependent variable used in this paper is the FDI stock p/c - NACE 1-digit - into the service sector for each observed CEE country in the period 1997-2006. In the case of our sample of countries, we have chosen from the pool of traditional and institutional-related determinants in the literature, and based on the availability of relevant indicators, the following set of possible FDI determinants have been chosen.

Using the set of data for CEE countries over ten years, empirical analysis was conducted by the regression assessment of panel data. We estimated OLS with panel-corrected standard errors (PCSEs) using Prais-Winsten to take into account the AR(1) process. Based on results of the research we created a proposal for sets of policies and strategies acceptable for the service sector and for attracting FDI in services.
\end{abstract}

Key words: Services, FDI, CEE Countries, Institutional Framework

\section{INTRODUCTION}

Foreign direct investment (FDI) phenomena are crucial elements in analyzing and recording the development of a modern economy. Their role in globalization is unquestionable. Consequently, the countries generating the most FDI are at the same time the leading ones.

Exploring FDI from the theoretical and practical point of view is the main point of evaluating the development of specific industrial and service area, and analyzing the development of transitional countries. This is especially important if one takes into consideration the fact that economic development of a transitional economy significantly depends on the foreign capital inflow. That is the reason why the relation between FDI and the level of economic development is very complex and multifaceted. Knowing that FDI inflow affects economic development and that the level of economic development and infrastructure has a positive influence on the attractiveness for FDI, it is sometimes very hard to evaluate the quality and direction of influence. 
On the other hand, the growth of service sector in the global economy has been accompanied by the growth in its share in the world transactions, as well as in FDI. Some studies have argued that the introduction of services requires a different approach, while others have had opposite views. However, as far as we know, there are no studies from, or on, a developing country. Service characteristics affect the manner of services trade or of their transfer between the countries. Their intangibility and non-storability imply that in order to become tradable, services have to be applied to, or embodied in objects, or information flow, or people. Thus, for trade to occur, the means of transportation of services often have to be able to cross national frontiers. This makes international transaction in services conceptually more complex than international transaction in goods. These characteristics differentiate services from goods and this has implications on the determinants of FDI in the service sector.

That was the reason for us to start researching the level, structure and factors influencing FDI inflow in services of CEE countries.. The goal of the paper was to test effects of the growing level of FDI in the service sector, and at the same time the factors that have the greatest influence on the level of FDI inflow, in order to find the most important factor that countries can implement through the policies and strategies for the promotion and attraction of FDI in services. According to these elements, the paper will propose policies and strategies for the attraction of FDI stock based on econometric analyses, which will include institutional-related determinants.

The paper consists of three main parts: the first discusses service characteristics and factors influencing FDI inflow, specifically in the service sector; the second discusses research methodology and the results we have obtained; and finally the third part stresses conclusions and recommendations for the future research.

\section{SERVICE CHARACTERISTICS AND FDI}

\section{Service characteristics}

The growing internationalization of services has led to a vast literature and some of the fiercest debates on critical issues regarding trade and investment in services. The increasing world trade in services can be partly attributed to the greater extent of liberalization (unilateral, bilateral and multilateral) undertaken by different countries and partly to the technological advances that have enabled higher tradability of services. Development of a greater array of discreet ,service-oriented“ products (such as software and interactive databases that can be easily accessed) has also been a key as it has created an effective medium for packaging and distributing storable knowledge and information.

Bhagawati (1984) argues that services can be divided into two categories: first, those that necessarily require the physical proximity of the user and the provider; and second, that do not essentially require this though it may be useful. The first group is particularly influenced by some of the servicespecific characteristics, pointed to by Hill (1997), Berry (1989) Kotler (1997), Langeard et.al. (1981), Bateson, Lovelock and Eiglier (1981), Gronroos (2007): intangibility, presence of customers at the service process, intangibility, perishability, absence of ownership and heterogeneity. The second group is less problematic from this point of view, and it could be analyzed more or less as the transaction in goods.

The basic characteristics of services that the most of the classifications are based on are: nontransferability and non-storability. The other associated characteristics of services that need to be 
noted are that services are heterogeneous and flexible in production, and that imperfect competition is highly relevant for services.

However, Bhagwati (1985) further argues that services for which physical proximity is inessential i.e. long distance services, are on the rise due to technological progress (services like banking and insurance fall under this category, as well as infrastructure and IT services). Such characteristics make international transaction in services as well as FDI in services more complex conceptually than in international transaction and FDI in goods. That is the main reason why it is important for host countries to find out if the same influential factors attract FDI in the service sector as in the manufacturing sector.

\section{Foreign direct investment in services}

Looking at the FDI development and its influence on globalization, the main purpose of most analyses is to outline those aspects and considerations which are relevant to any less developed economy in the promotion and attraction of FDI. The main interest is really related to identifying host-country characteristics that determine of FDI in general and more specifically, of FDI in services.

Factors and conditions that are important determinants of FDI inflow can be divided into two categories:

- Firm and industry-specific determinants: those factors induce the firm to invest abroad or at least offer an advantage or support for the internationalization of production, including such firmspecific or owner-specific factors such as managerial skills, product differentiation, technological lead and know-how; large size and market power, marketing and organizational expertise, R\&D capacity, etc.

- Host-country specific determinants: factor conditions, human resources, physical and natural resources, climate, location, unskilled labour and capital, but also advanced factors that are created such as modern infrastructure, universities, and highly skilled labour.

For the purpose of this paper, it is host-country specific characteristics that are more important as the influence factor on the FDI inflow into the country. The attractiveness of a country/locality as investment destination depends on the general development level of the country/locality. Transnational corporations (TNCs) look for countries which offer the best facilities for the lowest cost, but for the country it is important to find the correlation between the factors and the level of FDI inflow in order to stress and improve development of those factors during the process of FDI promotion. Often, small countries do better to attract market-seeking FDI within the context of regional cooperation, i.e., countries of the CEE or SEE group.

\section{THEORETICAL FRAMEWORK AND LITERATURE REVIEW}

FDI has grown faster than the global output and trade over the last two decades. This has given rise to a number of theoretical and empirical studies that have investigated its determinants and impact on the host economies. However, much of this literature has focused on FDI in manufacturing and very few studies exist for the service sector. This is an important gap in the literature since FDI in services has been found to grow even more rapidly than FDI in manufacturing. 
Starting from these specific characteristics of services, some of the conceptual issues identified under FDI in services are:

- What are the most important determinants of FDI in services?

- What are the implications for policies and strategies to attract FDI in services for developing countries?

Studies differ with respect to the framework used for service FDI. Some studies have applied theories that are applicable for FDI in goods (Chanda 1997, Schorath, and Korth 1988, Gray and Gray) while others have applied trade theories to service FDI (Helpman 1984, Marrkusen et al 1996).

Of the various theories put forward to explain FDI, Dunning's eclectic paradigm of international production (Dunning 1981) has been used by many studies (e.g. Chanda 1997). The theory combines the traditional theory of factor endowments with the theory of economic organization. According to this theory, the extent, pattern and growth of value-added activities by transnational corporations (TNCs) depend on their competitive advantages relative to local firms. These advantages include ownership, locational and internalisation advantages (OLI), i.e. the propensity for a firm to invest in foreign locations depends on a combination of, or on any one of, the following three elements: a) its ownership of core competencies or specific intangible assets that enhance competitive advantage; $b$ ) locational advantages that would derive from a transfer of operations onto a new region; c) internalisation advantages that may accrue to such investing firms.

Dunning (1989) identifies different ownership, locational and internalisation advantages of service transnational corporations. Rugman and Verbeke (1992) propose that a firm can successfully undertake direct investment abroad if it possesses some asset advantages, which may be location-bound or non-location bound. In case of service corporations such advantages consist of property rights of management, marketing and product innovation, exclusive or favoured access to input and product markets, access to technology and information, economies of joint supply in production, marketing, etc.

Engagement in foreign production would be motivated by companies' perception of their best interest to combine transferable advantages with some less mobile factor or some of locational advantages, in the form of tariff barriers, large markets, availability of resources at low cost, etc, in the case of goods, or input costs, infrastructural provisions, government regulation, size and character of local market, customers, competitors, etc. in the case of services.

In order to undertake FDI successfully, firms must be able to internalise their ownership advantages, since the need to internalise arises from transaction costs, which are the result of imperfect nature of the product and technology market (Hymer 197, Buckley and Casson 1976, Vernon 1966) and/or imperfections in the financial markets (Rugman 1982). Without the advantages of internalisation, FDI might be replaced by exports or licensing.

The other group of theories, ones that apply trade theory to FDI in services, insists on the fact that theory of FDI follows in many respects the theory of international trade. There are two distinct patterns of FDI: the "vertical" or inter-industry pattern, often found in FDI from developed countries (Helpman 1984) and "horizontal" or intra-industry, where relatively specific advantages within given industries between developed countries are exchanged. Most FDI is of the latter type.

Markusen et. al. (1996) show different types of relation between size of countries and type of FDI: a) vertical multinationals dominate in production when countries differ significantly in relative fac- 
tor endowments but are similar in size; b) horizontal multinationals dominate between countries similar both in size and available factors.

The two theories of FDI in services therefore differ with regards to their explanation as to why FDI rather than trade occurs, and what kind of FDI occurs. There are certain features of FDI in services that deserve exclusive attention, which are not covered in either of the two theories: how can FDI in services be transnationalised and what factors influence FDI inflow and attractiveness of countries in the process of internationalization of services?

All available econometric studies of service industries deal with financial industries. Yamori (1998) analyses Japanese finance industry FDI flows into 39 countries in the 1990-1999 period. Miller and Parkhe (1998) study the determinants of US banks' assets in 32 countries. And finally, Moshiran (1997) examines determinants of FDI stocks in the US insurance industry using time series data.

Market size is suggested as an important determinant of the finance sector FDI by both Yamori (1998) and Moshiran (1997), using GNP per capita and wealth as proxies for market size. Miller and Parkhe (1998) find a similar result for the banking sector, as host countries with a greater sum of deposits get more banking FDI. Market growth, however, appears to have a negative impact on FDI, as judged by the negative relationship between GNP change and FDI found by Yamori (1998).

\section{SECTORAL COMPOSITION OF FDI IN CEE}

Looking at the sectoral composition of FDI, the CEE countries (outside the CIS and SEE countries) are characterized by a high penetration of FDI in infrastructure services, e.g., telecommunications, water, electricity, and relatively smaller amounts of FDI (in global comparison) in business services and research and development (R\&D).

This issue arises due to the fact that, in many countries, FDI orientation toward services is related to the significant liberalization of direct investment regime and removal of discriminatory barriers for foreign investment in some service sectors (banking and financial sector specifically). On the other hand, growing FDI in services was influenced by the following:

- financial services industry globalization resulted in growing competition between different nonfinancial sources of credits and financial services (especially in the insurance market) which, in turn, led to the continuing consolidation of banking system in the mature and emerging markets (Roldos, 2001) and even by the need to open new markets according to the Ansoff model of development strategy.

- Foreign service companies' interest in emerging markets is conditioned by the possibility to use effects of economy of scale or scope derived from the technological advantages and the advantages of entry in the early phase of product or service life cycle.

- Many service companies guided by the language and cultural connections developed their activities regionally and focused on the specific region (i.e. CEE countries).

The growing presence of foreign service institutions is particularly notable in the financial systems of ,emerging markets“, or transitional economies (TE). The analyses of regulation in the area of FDI reveals that many emerging markets have reduced barriers for export and investment since 1990 in order to improve their own service efficiency and become part of organizations with diversified global portfolio (Roldos 2001). 
As discussed earlier, though a vast literature is available on the determinants of FDI in goods, very few empirical studies exist on the determinants of FDI into services. These include UNCTC (1993), Fukao and Ito (2000), Buch (2000), Chanda (2000), and Raff and Ruhr (2001). However, most of these studies are mainly undertaken for some of the prominent producer services, e.g., banking and insurance.

Drawing from various theories, for example eclectic paradigm, (Dunning 1988), internalization theory (Buckley and Casson 1976), oligopolistic reaction (Knickerbocker 1973), cultural distance (Hofstede 1980, Kogut and Singh 1988) and firm strategy (Kogut 1988, Porter 1990), as well as Markusen (1989) and EBRD indicators, the research results point out significant correlation between FDI inflow and the following variables, explained in the next section:

b) Overall transition indicators

1. Price liberalization

2. Competition policy

3. Banking reform and interest rate liberalization

4. Securities markets and non-bank financial institutions

b)Infrastructure reform

1. Telecommunications

Based on previous literature framework we have tested the following hypotheses:

Hypothesis 1: There is positive significant influence of each of the following factors: price liberalization, competition policy, banking reform and interest rate liberalization, as well as securities markets and non-bank financial institutions on the level of FDI inflow in service sector.

Hypothesis 2: There is positive significant influence of infrastructural reforms, specifically reforms in telecommunications, on the level of FDI inflow in the service sector.

Hypothesis 3: There is significant influence of GDP, inflation and wages on the level of FDI inflow in the service sector, as well as in the manufacturing one.

\section{MODELING AND DATA}

The sample of countries for analysis consists of eight transition countries that acceded to the EU in May 2004 (the Czech Republic, Poland, Hungary, Latvia, Lithuania, Estonia, Slovenia and Slovakia). The empirical framework employed in the analysis involved the use of a single equation model for testing the relationship between FDI in service and institutional infrastructure. The model regressed the FDI data on the measure of institutional development, and a set of control variables. The dependent variable in the paper was FDI stock per capita ${ }^{1}$ - NACE 1-digit - in the service sector for each observed CEE country in the period 1997-2006. Most FDI data were taken from the Vienna Institute for International Economic Studies (WIIW) database.

In recent years, multinational enterprises have increasingly focused on "created assets" (Narula \& Dunning, 2000), including knowledge-based assets, infrastructure and institutions of the host economy. Legal, political and administrative systems tend to be the internationally immobile framework whose costs determine international attractiveness of a location. Institutions affected the capacity of firms to interact, and therefore affected the relative transaction and coordination costs of production 
and innovation' (Mudambi \& Navarra, 2002: p. 636). Thus, institutional environment can be a significant location determinant in attracting FDI. In this paper, institutional development was measured based on a series of indicators of the transition process progress constructed by EBRD: Competition policy (CP), Banking reform \& interest rate liberalization (BR), Securities markets \& nonbank financial institutions (SM), Overall infrastructure reform (OI) and Telecommunications (T). Indices could take values from 1 to $4+$, whereby a higher index denotes getting closer to norms of developed market economies.

In some cases, there was some colinearity ${ }^{2}$ between the indicators of institutional development, as progress in various elements of the transition process often occurs simultaneously. For this reason, we tested the hypotheses by estimating series of equations, one for each institutional development index.

In order to ensure unbiased econometric estimates, our analysis controlled for a number of factors that the existing literature has identified as important determinants of FDI. A set of control variables was intended to capture those structural characteristics of the host economy that may attract FDI.

Most empirical studies on FDI in transition countries suggest that most enterprises in these countries invested in order to find new markets for their products/services, regardless of the industry the investment is made in (Lankes and Venables, 1996). A larger market represents a greater number of potential customers, potentially resulting in profit growth. Our model included GDP per capita which is a proxy for the purchasing power of local consumers (local demand) and market size. We expected a positive sign for this variable: countries with higher purchasing power of their consumers are expected to attract more foreign investors.

Besides the size and dynamics of the market and access to the host market, the prevailing factors for attracting FDI certainly include the cost and quality of input factors (Neuhaus, 2005). The analysis considered wages as an independent variable, as a proxy variable for input cost. We calculated unit labor costs as the ratio of the annual average wage in each economy to GDP per capita in each economy. In this way, our measure of unit labor cost was effectively a unitless ratio (Bevan et al, 2004).

Successful implementation of economic reforms in transition countries is a good sign to potential investors, since the stable macroeconomic performance implies a lower risk for investment. In this context, price stability is a good indicator for host governments' macroeconomic management. The sustainability of moderate or low inflation tells investors how successful the host government is and thus the prospect of further growth. Thus, the lower the average inflation rate is in the host country, the more foreign investment will be attracted to the country (Kinoshita and Campos, 2002). The study therefore approximated macroeconomic stability with the inflation rate. We expected the higher inflation to have a negative effect on FDI inflows in the service sector, i.e. the coefficient to be negative.

${ }^{1}$ There are several advantages in working with FDI stocks rather than flows. First, foreign investors decide on the worldwide allocation of output, hence on capital stocks. Second, stocks account for foreign direct investment being financed through local capital markets, hence it is a better measure of capital ownership (Devereux and Griffith, 2002). Finally, stocks are much less volatile than flows which are sometimes dependent on one or two large takeovers, especially in relatively small countries (Quere et al, 2005). Data have been aggregated as the result of authors' calculation using data from the Vienna Institute for International Economic Studies (WIIW) database.

${ }^{2}$ Correlations matrix is not presented due to space limitations 
Liberalization of trade could be closely related to FDI, because it could make the country more attractive for foreign investors. The paper used the shares of imports and exports in the observed countries' GDP as the degree of openness. The expected sign of the coefficient with this variable was positive.

Data used for independent variables were mainly those from the Vienna Institute for International Economic Studies (WIIW) Handbook of Statistics 2008. Despite the fact that there were different sources for independent variables, the goal was to use data only from a couple of sources in order to avoid problems due to different ways of defining variables and the way of data collection, at least in terms of independent variables.

The model we estimated to depict the determinants of FDI is as follows:

$\mathrm{FDI}_{\mathrm{it}}=\mathrm{a}+\gamma_{\mathrm{i}}+\hat{\mathrm{a}}_{1} \mathrm{GDPpc}_{\mathrm{it}}+\hat{\mathrm{a}}_{2} \mathrm{OPENESS}_{\mathrm{it}}+\hat{\mathrm{a}}_{3} \mathrm{WAGE}_{\mathrm{it}}+\hat{\mathrm{a}}_{4}$ INFLATION $_{\mathrm{it}}+\hat{\mathrm{a}}_{5}$ INSTITUTIONAL $_{\mathrm{it}}$ $+\mathrm{e}_{\mathrm{it}}$

where:

$\mathrm{a}=$ the constant

$\gamma_{\mathrm{i}}=$ country fixed effects

$\mathrm{GDPpc}_{\mathrm{it}}=$ per capita GDP of country $\mathrm{i}$ in year $\mathrm{t}$

OPENESS $_{\mathrm{it}}=$ ratio of the foreign trade of country $\mathrm{i}$ to its GDP in year $\mathrm{t}$

$\mathrm{WAGE}=$ real wages of country $\mathrm{i}$ in year $\mathrm{t}$

INFLATION $_{i t}=$ consumer price index of country $\mathrm{i}$ in year $\mathrm{t}$

INSTITUTIONAL = institutional related variables $\mathrm{CP}, \mathrm{BR}, \mathrm{SM}, \mathrm{T}$ and $\mathrm{OI}$ of country $\mathrm{i}$ in year $\mathrm{t}$

$\stackrel{\circ}{\mathrm{a}}_{\mathrm{it}}=$ the error term.

Since all variables are expressed in logs, the estimated coefficients should be interpreted as elasticities.

We used a panel data set covering eight CEE transition economies between 1997 and 2006. Data were not available for all the eight countries for all the years, and the dataset is therefore "unbalanced". Given the longitudinal nature of the dataset, we began by estimating equation (1) with country fixed effects model $(\mathrm{FEM})^{3}$. Use of pooled data in econometric analyses frequently leads to certain complications (Hicks 1994, 171-72). First, errors tend not to be independent from one period to the other. In other words, they might be serially correlated, such that errors in country $i$ at time $t$ are correlated with errors in country $i$ at time $t+1$. Second, the errors tend to be correlated across nations. They might be contemporaneously correlated, such that errors in country $i$ at time $t$ are correlated with errors in country $j$ at time $t$. Third, errors tend to be heteroschesdastic, such that they may have differing variances across ranges or subsets of nations. And fourth, errors may contain both temporal and cross-sectional components reflecting cross-sectional effects and temporal effects. In other words, even if we started with data that were homoschedastic and not auto-correlated there was a risk of producing a regression with observed heteroschedastic and auto-correlated errors. This is because heteroschedasticy and auto-correlation we observe is also a function of model misspecification. This is why we applied tests for checking the presence of heteroschedasticity and autocorrelation. First, a modified Wald test for groupwise heteroschedasticity in fixed effect regression model reveals the presence of heteroschedasticity which, while leaving coefficient estimates unbi-

${ }^{3}$ Results for the FEM model are not presented due to space limitations 
ased, can significantly influence standard errors and therefore affect hypothesis testing. There are number of statistical techniques that can address this problem (e.g. weighted least squares), but their applicability and implementation are less clear in a panel context.

In addition to heteroschedasticity, the estimates using FEM model are also affected by serial correlation. In particular, a Wooldridge test for autocorrelation in panel data rejects the null hypothesis of no first order serial correlation. The consequences of autocorrelation were similar to heteroschedasticity, but the problems caused by the latter are usually more severe. OLS coefficient estimates remain consistent and unbiased in the presence of autocorrelation, but they were no longer best linear unbiased estimators (BLUE) or asymptotically efficient. Furthermore, autocorrelation causes standard errors to be biased.

Consequent to the previously described problems, both Parks-Kmenta method and Beck and Katz's (1995) proposal were alternatives. They represented two different approaches to tackle the complications of serial correlation, contemporaneous correlation and heteroschedasticity. Beck and Katz showed that the overconfidence in the standard errors made the Parks-Kmenta method unusable unless there were more time points than there were cross-section units. In other words, they recommended using Parks only when $\mathrm{T}$ is very large relative to $\mathrm{N}$, which was not the case in this research ( $\mathrm{T}$ is almost identical to N). Nonetheless, Beck and Katz (Beck and Katz, 1995) showed that these approaches significantly underestimated the variability of the estimated coefficients, especially if the sample size is small. In this study, we followed the suggestions of Beck and Katz and estimated OLS with panel-corrected standard errors (PCSEs) using Prais-Winsten to take into account the AR(1) process.

\section{PANEL REGRESSION RESULTS}

In Table 1 we reported the results separately for each of the observed measures of institutionalrelated variables combined with the same set of control variables.

Table 1: Panel regression results

\begin{tabular}{|c|c|c|c|c|c|}
\hline & Model 1 & Model 2 & Model 3 & Model 4 & Model 5 \\
\hline \multirow[t]{2}{*}{ GDP_pc } & $0,57 * *$ & $0,65^{* * *}$ & $1,03 * * *$ & $0,63^{*}$ & 0,47 \\
\hline & $-0,26$ & $-0,22$ & $-0,28$ & $-0,35$ & $-0,33$ \\
\hline \multirow[t]{2}{*}{ Openness } & $0,19 * * *$ & $0,73 * *$ & $0,93 * *$ & $1,25 * * *$ & $0,72 * *$ \\
\hline & $-0,4$ & $-0,38$ & $-0,4$ & $-0,43$ & $-0,37$ \\
\hline \multirow[t]{2}{*}{ Wage } & 0,35 & 0,31 & 0,1 & $0,57^{*}$ & $0,60 * *$ \\
\hline & $-0,25$ & $-0,21$ & $-0,31$ & $-0,33$ & $-0,29$ \\
\hline \multirow[t]{2}{*}{ Inflation } & $-0,15^{* * *}$ & $-0,14 * * *$ & $-0,14 * * *$ & $-0,13 * * *$ & $-0,10 * *$ \\
\hline & $-0,05$ & $-0,05$ & $-0,05$ & $-0,05$ & $-0,04$ \\
\hline $\mathrm{CP}$ & $\begin{array}{c}1,69 * * * \\
-0,34\end{array}$ & & & & \\
\hline BR & & $\begin{array}{c}2,59 * * * \\
-0,65\end{array}$ & & & \\
\hline SM & & & $\begin{array}{c}1,17 * * \\
-0,5\end{array}$ & & \\
\hline $\mathrm{T}$ & & & & $\begin{array}{c}0,76 * * * \\
-0,28\end{array}$ & \\
\hline OI & & & & & $\begin{array}{c}1,78 * * * * \\
-0,46\end{array}$ \\
\hline $\mathrm{R}-\mathrm{sq}^{2}$ & 0,79 & 0,81 & 0,79 & 0,8 & 0,81 \\
\hline Prob $>$ chi 2 & 0 & 0 & 0 & 0 & 0 \\
\hline $\mathrm{N}$ & 74 & 74 & 74 & 74 & 74 \\
\hline
\end{tabular}


Source: Authors' calculations

Note: Robust standard errors in parentheses. Asterisks indicate variables whose coefficients are significant at the $10 \%(*), 5 \%(* *)$, and $1 \%(* * *)$ level, respectively. All regressions include constant and country dummies (not reported in the table).

${ }^{2}$ There is no precise counterpart to $\mathrm{R}^{2}$ in the generalized regression model. The $\mathrm{R}^{2}$ from the transformed model is purely descriptive (see Greene 1999).

Turning first to the results for the control variables, we noted that the variables displayed the correct sign. FDI is positively related to GDP p/c and was always statistically significant except in model 5. Therefore, larger markets, which recorded faster economic growth, offered better opportunities for service industries to make use of their ownership advantages, which in turn led to a greater FDI inflow into this sector. Surprisingly, wages were insignificant although they had the expected sign in all the models. A possible explanation could be the use of average wages in the analysis, rather than the wages in the industry, since such data were not available for all the observed countries. Moreover, one of the possible explanations was that cheap but relatively skilled labour, although a favorable factor for investment, characterized most of the transition economies that competed with each other for foreign investment. Therefore it could not be a specific advantage of any of these economies individually, and could not help attract foreign investors. Inflation manifests statistical significance at the level of $1-5 \%$ and has the negative algebraic sign, as initially presumed. Macroeconomic instability, traditionally determined on the basis of the persistent rise of price levels, increases the commercial risk of investment. High inflation weakens the foreign investors' confidence in capability and readiness of the recipient country government to maintain a consistent monetary policy, stable prices and currency should their economies be exposed to turbulence of a greater scope. The fear of shock therapy which could cause losses inevitably affects the decision on possible investment in service industries. Openness was always a highly significant variable that exerted a positive influence on the FDI in the service sector of CEE countries.

The analysis of significance and impact of the institution-related variables on the FDI stock in service sector covered a series of progress indicators in the process of transition, developed on the basis of EBRD methodology. All of the five analyzed indicators in the model showed a considerable statistical significance (1\%, and 5\%) and, as expected, positively influenced FDI, thus empirically confirming the main initial hypothesis that establishing and strengthening institutions of market economy leads to the increase of FDI inflow into the service sector of the CEE countries. ${ }^{4}$

\section{CONCLUDING REMARKS}

The purpose of this paper was to assess correlation between factors influencing FDI level, based on the referenced literature, but in the area of services. Since there are significant differences between goods and services there is a need to find possible differences between the factors influencing FDI inflow in the service area. The main goal of the research was to find the factors which countries

${ }^{4}$ Given that the eight countries of Central and Eastern Europe are highly convergent in terms of their level of economic performance as well as in terms of achieved structural reforms, some of the analyzed institution-related variables BR and SM did not manifest sufficient variability (within standard deviations $<0,05$ ). The coefficients on variables with small within standard deviations may not be as well identified as the others. Given coefficients and standard errors for mentioned variables are high and that is the consequence of the problem that was observed. 
could use as the basis for development of policies and strategies to promote and attract FDI in services.

We have found significant positive relation and influence of GDP and market openness on the level of FDI inflow in the service sector, which was the relation confirmed in econometric analyses of the total FDI inflow, as well as FDI inflow in the manufacturing sector. Significant negative correlation between inflation rate and FDI inflow has been found; this was also expected, since it implied inadequate macroeconomic environment as one of critical variables likely to affect the location of FDI. However, we found atypical relations - compared to FDI inflow in the manufacturing sector - between the level of average wages and FDI inflow: the average level of wages had a negative, though not significant influence on the decision about a possible sector for investment. A probable explanation for this type of connection could be found in theories and motives for investment in the service sector. Motives for this type of investment do not include cheap labor, since service companies trying to transnationalise look for professional and skilled employees, and they are by no means motivated with the level of wages.

In the research we have found significant positive relation between tested variables: competition policy, banking reform and interest rate liberalisation, securities markets \& non-bank financial institutions. It means that Hypothesis 1 and Hypothesis 2 have been confirmed completely, while Hypothesis 3 was partially confirmed. Practically, we rejected a part of Hypothesis 3 pertaining to the level of average salaries as a motive for investment in the service sector.

These conclusions indicate that CEE countries that want to promote and attract FDI in services should follow results and correlation between the factors tested in the research, but at the same time, insist on improvement of the lower-ranked areas:

- Looking at the price liberalization and competition policy, there is a pattern of the activities CEE countries are involved in. They are ranked fairly high in the price liberalization area, which means that they have created relatively open markets for domestic and international supply, in line with the neo-liberal arguments for creating a relatively or completely free market without government influence. At the same time, all countries are ranked below average in the competition policy, which in turn implies that there is a negative perception about their ability to compete on the CEE countries' markets. A possible reason for these results is the fact that some of the CEE countries try to protect the domestic service area. A specific example of this pattern may be Slovenia, the country insisting on controlling the level of FDI inflows into the banking and financial sector. There are several other countries trying to keep at least a part of the service sector (public services, or financial services) domestically owned. Until all of them accept the request for privatization and deregulation of all these sectors, both levels and ranks will remain low. If CEE countries want to attract a high level of FDI inflow in services, they have to accept strong deregulation of the service sector. It is a kind of global interventionism aiming to globalize and transnationalise these services.

- Further implementation of banking reforms and liberalization of financial services market is important for all countries in the region, except for Czech Republic, Estonia and Hungary. They are marked with 4 in 2005 and 2006 and very close to achieve standards and performance norms of advanced industrial economies: full convergence of banking laws and regulation with BIS standards; provision of a full set of competitive banking services.

- Development of securities markets \& non-bank financial institutions. This is owing to the fact that in most of the researched countries, financial sector consists mainly of banking institutions, which implies that they have to further develop other dimensions and subjects in this area, as 
well as to create securities markets. The recommendation practically applies to all the countries in the region, except Hungary, which was marked with 4 in the last year of the assessment.

- Looking at the overall infrastructure reforms, the ranking of average reform indicators in the electricity sector, researched countries have got the lowest indicators compared to the average of assessed areas. Based on them one could conclude that there is a need to continue the reforms.

- Looking at the telecommunication sector, excluded from the infrastructure reforms, the situation is much better. Most of the countries were marked 4 or $4+$ since they have implemented complete commercialization, including the privatization of a dominant operator; comprehensive regulatory and institutional reforms, extensive liberalization of entry or effective regulation through an independent entity, coherent regulatory and institutional framework to deal with tariffs, interconnection rules, licensing, concession fees and spectrum allocation, and consumer ombudsmen function.

- Strengthen further legislative frameworks to ensure consistency with international standards and conventions. Ensure that policies in the CEE countries are in line with the OECD Guidelines for Managing Conflict of Interest in the Public Sector, and that appropriate resources are allocated for implementation. Strengthen public procurement institutions through regular training of public officials and monitoring of procurement cases. Implement and regularly monitor anticorruption policy, focusing on the evaluation of the effectiveness of policies in place and on the use of risk assessment techniques to identify future priorities. Institutionalize regular, sustainable consultation mechanisms, with representatives of businesses for policy development, implementation and monitoring in all countries.

These results, which are confirmed by econometric studies and surveys on firms' investment intentions, are useful pointers to governments wishing to attract such investment. They also suggest that these same governments need to pay constant attention to upgrading and reconfiguring their own unique, location-bound advantages (both actual and potential) and to focus on attracting the kind of FDI that might help them best accomplish this objective. 


\section{REFERENCES}

Banga Rashmi, Trade and Foreign Direct Investment in Services: A Review, Working Paper No. 154, Indian Councile for Research on International Economic Relations, February 2005, pp 22

Baum C.F. (2006). An Introduction to Modern Econometrics Using Stata, A Stata Press Publication, StataCorp LP, College Station, Texas

Beck, N \& Katz J.N. (1995). What to Do (and Not toDo) with Time-Series-Cross-Section Data, American Political Science Review 89(3): 634-47.

Bevan et. al. (2004). Foreign investment location and institutional development in transition economies, International Business Review 13 (2004) 43-64

Bevan, A. \& Estrin, S. (2000). The determinants of foreign direct investment in transition economies, CEPR Discussion Paper No. 2638. London: Centre for Economic Policy Research

Bhagwati, Jagdish (1996) International Trade in Services and Its Relevance fr Economic Development, in Bhagwati-Jagdish, Political economy and international economics. Edited by Douglas A. Irwin. Cambridge and London: MIT Press, 1996; 235-69, previously published. 1987

Bhagwati Jagdish (1991) Trade in Services and the Multilateral Trade Negotiations", Bhagwati Jagdish, Political economy and international economics. Edited by Douglas A. Irwin. Cambridge and London: MIT Press, 1996; 282-306, previously published. 1987

Blattner, T. (2002). Foreign Direct Investment in Transition, paper presented at the seminar on 'Europaische Kapitalmarkte im Wandel: Theorie und Empirie', Free University Berlin, Department of Economics, Institute for Economic Policy and Economic History

Bhagwati Jagdish (1989), Is Free Trade Passe after Al?" Weltwirtschaftliches-Archiv; 125(1): 17-44

Buch, C.M. (2000), "Why do Banks Go Abroad? Evidence from German Data", Financial Markets, Institutions and Instruments.

Buckley, P.J. and Casson, M.C. (1976), “The Future of the Multinational Enterprise”, Homes \& Meier: London

Buigues, P. and Jacquemin, A. (1994). Foreign Direct Investment and Exports to the European Community, in M. Mason and D. Encarnation (eds.) Does Ownership Matter: Japanese Multinationals in Europe, Oxford and New York: Oxford University Press

Chanda Rupa (1997), Trade Liberalization and Foreign Direc Investment in Producer Services: A Theoretical and Empirical Study”, Working Paper, IIM Bangalore, September 1997

Chanda Rupa (2000), "Impact of Trade Liberalization of Foreign Direct Investment in Producer Services”, working paper 103, IIM, Bangalore, September.

Delali, A. (2003). The Determinants and Impacts of Foreign Direct Investment, MPRA Paper No. 3084, http://mpra.ub.uni-muenchen.de/3084/, (30/01/09)

Dunning, J. H. (1981), "Explaining the International Direct Investment Position of Countries: Towards a Dynamic or Developmental Approach", Weltwirstchaftliches-Archiv. 117(1): 30-64 
Dunning, J.H. (1988). The Eclectic Paradigm of International Production: A Restatement and Some Possible Extensions, Journal of International Business Studies, vol.19, pp.1-31

Dunning, J.H.,, (1989), “Trade and Foreign-Owned Production in Services: Some Conceptual and Theoretical Issues", Giersch-Herbert, ed. Services in world economic growth: Symposium 1988. Tubingen, West Germany: Mohr (Siebeck); Boulder, Colo. and London: Westview Press; 108-50.

Dunning, J.H. (2005). Towards a New Paradigm of Development; Implications for the Determinants of International Business Activity, Mimeo, Universities of Reading and Rutgers.

Dunning, J.H. \& Buckley. P.J. (1977). International Production and Alternative Models of Trade, Manchester School of Economic and Social Studies, vol.45, pp.393-403

Fukao Kyojy and Keiko Ito (2000), Foreign Direct Invesment and Service Trade: The Case of Japan, Hitotsubashi University, mimeo.

Gray, J.M and Gray, H. (1981) The multinational bank: A financial multinational corporation?", Journal of Banking and Finance 5(1), 33-63

Gronroos, Ch. (2007), “Service Management and Marketing” $3^{\text {rd }}$ ed., John Wiley \& Sons, Ltd

Helpman, E. (1984), “A Simple Theory of International Trade with Multinational Corporations", Journal of Political Economy, June 92(3), 451-71.

Hill P. (1997), “On Goods and Services”, The Review of Income and Wealth, Vol. 23. No. 4.

Holland, D. \& Pain, N. (1998). The diffusion of innovations in Central and Eastern Europe: A study of the determinants and impact of foreign direct investment, NIESR Discussion Paper No. 137, London: National Institute of Social and Economic Research.

Hymer, S. (1976), International operations of national firms: A study of direct investment. Cambridge, Mass: MIT Press.

Kinoshita,Y. \& Campos N. (2003). Why Does FDI Go Where it Goes? New Evidence from the Transition Economies, Williamson Institute working paper, 573.

Lankes, H. P. \& Venables, A. J. (1996). FDI in economic transition: the changing pattern of investments. Economics of Transition, 4(2), 331-347.

Lansbury, M., Pain, N., \& Smidkova, K. (1996). Foreign direct investment in Central Europe since 1990: An econometric study. National Institute Economic Review, 156, 104-124.

Markusen,, J.R. et al (1996), “A Unified Treatment of Horizontal Direct Investment, Vertical Direct Investment and the Pattern of Trade in Goods and Services", National Bureau of Economic Research, In. NBER Working Papers: 5696

Miller, S.R. and Parkhe, A. (1998), "Patterns in the expansion of U.S. banks' foreign operations", Journal of international business studies, 29, 2, 359-390

Moshirian, F. (1997), "Foreign direct investment in insurance services in the United States", Journal of multinational financial management, 7, 159-173 
Mudambi, R., Navarra, P. (2002): Institutions and International Business: a theoretical overview, International Business Review.646-635:(6)11,

Neuhaus, M. (2005). The Impact of FDI on Economic Growth, An Analysis for the Transition Countries of Central and Eastern Europe ,'Physica-Verlag, A Springer Company

Podesta, F. (2000). Recent developments in quantitative comparative methodology: the case of pooled time series cross-section analysis, DSS PAPERS SOC 3-02

Pournarakis, M. \& Varsakelis, N. (2004). Institutions, internationalization and FDI: the case of economies in transition, Transnational Corporations, vol. 13 (2), August 2004, pp. 77-94.

Quere, A. B. et al. (2005). Institutional Determinants of Foreign Direct Investment, CEPII, Working Paper No 2005-05.

Raff, H. and M. von der Ruhr (2001), Foreign Direct Investment in Producer Services: Theory and Empirical Evidence", Mimeo, University of Kiel.

Resmini, L. (2000). The determinants of foreign direct investment in the CEECs: New evidence from sectoral patterns, Economics of Transition, 8(3), 665-689.

Schroath, F.W. Korth, Ch.M. (1989) Managerial Barriers to the Internationalization of U.S. Proper5ty and Liability Insurers: Theory and Perspectives" Journal of Risk and Insurance, December 56 (4): $630-48$

Sauvant, K.P. (1990), “The Tradability of Services”, Messerlin-Patric-A.; Sauvant, K.P. eds. The Uruguay Round: Services in the world economy. With contributions by Bela Balassa et al Washington, D.C.: World Bank; New York: United Nations Centre on Transnational Corporations, 114-22.

Vernon, R. (1966), "International investment and international trade in the product cycle", Quarterly Journal of Economics, May, 80 (2), p. 190-207.

World Bank. (1996). World development report. Washington, DC: Oxford University Press.

Yamori, N. (1998), “A note on the location choice of multinational banks: The case of Japanese financial institutions", Journal of banking and finance, 22, 109-120 